\title{
Study of the influential factors on the rheological behavior of adhesive mortar available in the market
}

\author{
Estudo dos fatores influentes no comportamento \\ reológico de argamassas colantes de mercado
}

M. R. M. M. CostA a mariennecosta@uol.com.br

E. PEREIRA engenheiroeduardopereira@gmail.com

R. G. PILEGGI ${ }^{\circ}$ rafael.pileggi@poli.usp.br

M. A. CINCOTTO cincotto@poli.usp.br

\begin{abstract}
Rheology studies the deformation and flow of matter and seeks to describe the deformations of material depending on the time they are exposed to mechanical actions. This paper proposes to understand the behavior of fresh mortar adhesives in Squeeze Flow tests based on rheological characterization of different commercial compositions. In the tests, flow of material results from the application of a compressive load on the sample in the fresh state which causes displacement due to stresses generated during radial shear flow. We performed further physical characterizations of mortars and viscosity on material passing the through a sieve with a $0.075 \mathrm{~mm}$ sieve opening with the objective of basing the analysis of the results obtained from Squeeze Flow tests. It was observed that the mortars studied showed differences in rheological behavior, probably resulting from synergistic action of some of the composition parameters, especially the particle size distribution and particle morphology.
\end{abstract}

Keywords: rheology; squeeze flow test; particle size distribution; morphology; adhesive mortar.

\section{Resumo}

A reologia estuda a deformação e o escoamento da matéria buscando descrever as deformações dos materiais dependentes do tempo, quando os mesmos são expostos a ações mecânicas. O presente trabalho propõe o entendimento do comportamento no estado fresco de argamassas colantes, com base na caracterização reológica de diferentes composições comerciais, a partir do ensaio "Squeeze Flow". Neste ensaio, o escoamento do material decorre da aplicação de uma carga de compressão sobre a amostra no estado fresco, a qual ocasiona deslocamentos no seu interior, devido a esforços de cisalhamento radiais originados durante o fluxo. Foi realizada ainda a caracterização física das argamassas e a viscosidade da fração passante na peneira da fração passante na peneira de abertura $0,075 \mathrm{~mm}$, com o objetivo de embasar a análise dos resultados obtidos com o Squeeze Flow. Observou-se que as argamassas estudadas apresentam diferenças de comportamento reológico, decorrente provavelmente, de ação sinérgica de alguns parâmetros da composição, com destaque para a distribuição granulométrica e morfologia das partículas.

Palavras-chave: reologia; squeeze flow teste; distribuição granulométrica; morfologia; argamassa colante.

\footnotetext{
Departamento de Construção Civil da Universidade Federal do Paraná - UFPR, mariennecosta@uol.com.br, Curitiba, Brasil; Departamento de Construção Civil da Universidade Federal do Paraná - UFPR, engenheiroeduardopereira@gmail.com, Curitiba, Brasil; Departamento de Engenharia Civil Escola Politécnicna da Universidade de São Paulo - USP, rafael.pileggi@poli.usp.br, São Paulo, Brasil;

Departamento de Engenharia Civil Escola Politécnicna da Universidade de São Paulo - USP, cincotto@poli.usp.br, São Paulo, Brasil.
} 


\section{Introduction}

Adhesive mortars consist of cement, aggregate and other additives. The most common industrially produced additives are cellulose ethers (HEC e MHEC) and latex polymers (PVA). Each perform specific functions in fresh and hardened mortars [1]. Latex additives improve the rheological behavior of fresh mortars, but mainly provides flexibility and tensile strength for hardened mortars [2]. Ethers are water soluble polymers and small amounts of polymer increases water retention and viscosity in mortars [3, 4]. Quartz sand, with dimensions less than $0.50 \mathrm{~mm}$, is predominantly used in mortar. Characteristics, such as shape, texture and grain size, have a significant influence on the workability and adhesion of mortar [5]. The shape and texture of the grains are primarily responsible for changes in the friction coefficient. Mendes [6] demonstrated that the more rounded the particles, the lower the friction coefficient compared to those that are irregularly shaped. Pereira [7] found that the shape of particles larger than $0.090 \mathrm{~mm}$ significantly influence the flow phenomena of mortar and the more rough the particles, the greater the shear required for the flow of the mixture.

Another issue related to the influence of particle size distribution is the degree of compaction. The ideal condition is to gradually fill the larger voids with smaller grains [8]. It should be noted, however, that you should not utilize an excess of fines as they may increase the surface area, hence increasing the amount of water needed to coat the particles. Sand with elevated fineness increases the water consumption in the mixture, which may cause significant shrinkage in the mortar after water evaporation, and fine sand may fill the pores of the substrates occupying the spaces of the hydration products $[5,9]$.

Moreover, an increase in the proportion of sand, maintaining the same amount of water in the mixture, decreases the workability of the mortar, thus influencing the development of adhesive strength of the coatings. It should also be considered that increased coarseness in the sand could cause inefficient distribution of the grains in the cement mixture leading to difficulty in mortar flow and compromising adhesion [9]. However, it should be emphasized that an adequate proportion of sand is essential for the formation of the undeformed skeletal structure of the mixture and to reduce mortar shrinkage.

The fineness of cement has a significant influence in adhesive mortar. Different cements exhibit different physical characteristics. However, fineness is the most significant parameter [10]. The finer the particles of cement, the more water and additives are required for the same workability.

From the perspective of rheological behavior, it is assumed that mortar adhesives are concentrated suspensions of solid particles immersed in a viscous liquid which has the function of ensuring the cohesion of the system and providing lubrication and space for the movement of aggregates [8]. If the volume of the matrix is not sufficient, the rheological characteristics and properties of the mortar is harmed $[11,6]$. With increased matrix content, fluid flows more easily and fluidity of the system will be governed by the viscosity of the matrix. Thus, to understand the rheology of the fluid and have a global view of rheological behavior, it is necessary to analyze the phenomena that occur in the matrix, such as those derived from aggregate [12].

To define the behavior of mortar in its fresh state we frequently use consistency parameter data obtained from tests Flow Table and the Dropping Ball tests [13]; the so-called monopoint tests. However, as easy as these tests are to perform, they present conceptual limitations in the characterization of mortars. It is not possible to describe the behavior of material by a single measurement. But, it should be measured by a rheological profile test that, preferably, simulates actual conditions since behavior can vary depending on the characteristics of the actual application [14].

To fill this limitation gap, the Squeeze Flow test was developed. It provides for the characterization of rheological behavior through viscosity and yield parameters and is the defined as standard test NBR 15839 [15]. Despite the aforementioned standard, it is not specific for the analysis of adhesive mortars. But, this methodology is being used successfully by various researchers $[8,7,16]$ along with adaptations and adjustments to the test apparatus.

Within the above-mentioned context, the objective of this work is to understand the behavior of fresh mortar adhesives based on rheological characterization of different Brazilian commercial compositions. An understanding of the rheological behavior of adhesive mortar is the basis for a technological breakthrough, considering that their application is in a fluid state.

\section{Experimental program and materials}

The experimental program was designed with the objective of correlating the physical characteristics of mortar adhesives in the market, such as particle size, particle morphology and air content, with their rheological behavior determined from Squeeze Flow test parameter characteristics.

\begin{tabular}{|c|c|c|c|c|c|c|}
\hline \multicolumn{7}{|c|}{$\begin{array}{l}\text { Table } 1 \text { - Detail of the preliminary data of the samples } \\
\text { (Slip and water/dry materials ratio in the pastes and mortars) }\end{array}$} \\
\hline & \multicolumn{6}{|c|}{ Adhesive mortar and paste } \\
\hline & $A^{(G)}$ & $B^{(\theta)}$ & $C^{(M)}$ & $D^{(B)}$ & $\mathbf{E}^{(\mathrm{M})}$ & $F^{(B)}$ \\
\hline $\begin{array}{l}\text { Amount of water indicated by the manufacturer } \\
\text { for adhesive mortar }(\mathrm{ml} / \mathrm{Kg})\end{array}$ & 230 & 220 & 200 & 230 & 230 & 200 \\
\hline Proportion water/dry mix materials for paste $(\mathrm{ml} / \mathrm{g})$ & 1.1 & 1.1 & 0.9 & 0.9 & 1.2 & 0.9 \\
\hline Slip test results of mortar (mm) & 0.5 & 0.5 & 0.7 & 3.4 & 1.1 & 5.9 \\
\hline
\end{tabular}




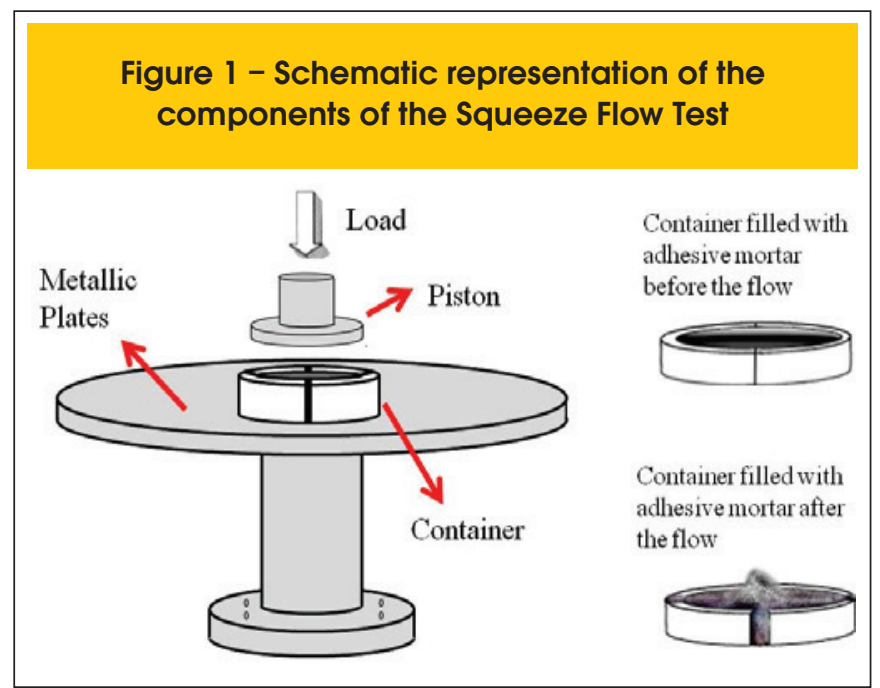

\subsection{Definition of the sample universe}

Initially, one bag each of thirty different brands of type AC-I adhesive mortar [17] was acquired from building material dealers throughout Brazil. Classification rules, based on manufacturer's specifications, were considered for the type AC-I mortar. In order to reduce the initial sample size and provide a parameter for selecting the mortars used in the research, each mortar was subjected to a slip test, as determined by NBR 14085 [18]. In this test, the mortar was applied on a substrate pattern and the strings were formed in transverse direction to the substrate. Ceramic tiles were positioned within the strings and the substrate was placed in an upright position in order to observe for sliding of the tiles.

Based upon the sliding results, six brands were chosen for the sample universe. Two brands were below the limit specified by NBR 14081 [17]. Two were at the limit. And, two were above the specified limit. The maximum sliding was specified at $0.7 \mathrm{~mm}$. Table 1 reflects the sliding results of the mortar chosen. The relation of water/fine fraction dry material was obtained by mixing with the water content specified by the mortar manufacturer with respect to the proportion of fine fraction of each mortar. For example, if the amount of water indicated for mortar A was $230 \mathrm{ml} / \mathrm{kg}$ and the fine fraction was $21.8 \%$ of the mortar mass, then the ratio of water/dry material for mortar A would be equal to 1.1 , or $230 \mathrm{ml} / 218 \mathrm{~g}$. The water content used was specified by the manufacturer product packaging. Table 1 also reflects the amount of water recommended by the mortar manufacturers selected, in addition to the amount used.

\subsection{Physical characteristics of the adhesive mortars}

\subsection{1 - Anhydrous state}

Mortar was physically characterized in the anhydrous state by grain size and grain morphology. Bulk density was measured to assist in determining the amount of incorporated air. We determined the complete granulometric curves by using screening test, with the normal series of ABNT sieves, on the mortar and a laser particle size analyzer for the fraction passing through the No. 200 sieve ( $0.075 \mathrm{~mm}$ opening). Industrialized materials were also utilized in a reconstruction approximating the amounts of components in procedures recommended by Quarcioni [19]. The aggregate particles retained in sieve openings of $0.6,0.3$ and $0.15 \mathrm{~mm}$ were analyzed for their morphology in order to determine texture differences and form irregularities between the particles. The particles measuring above the $0.6 \mathrm{~mm}$ were not analyzed due to the small amount within this range. The particle study was performed using images acquired by a stereoscopic Zeiss, Stemi model 2000-C. For each mortar, a minimum of 100 grains were photographed in each sieve. Morphological analysis of the aggregate was performed utilizing an IMAGO program, version 2.2.4 loaned to us by the business ESSS[20]. The technique could not be applied to the portion of material passing through the $0.075 \mathrm{~mm}$ sieve opening because of the natural agglomeration of the grains. Their small size prevented them from appearing individually in the images.

\subsection{2 - Fresh state}

In the fresh state mortar was rheologically evaluated by the Squeeze Flow test, in addition to determining densities and the amount of incorporated air. In characterizing the rheological behavior of adhesive mortar in the Squeeze Flow test, the flow of material resulting from the application of a compressive load on the fresh state sample caused shifts in its interior due to the radial shear forces created during the flow. To execute this test the equipment used was a universal test machine commonly existing in building construction material laboratories for measuring application load sample as described in NBR15839 [15]. The details of the test employed are indicated in Figure 1. The movable punch has the same diameter as the sample in order to ensure the load application on the entire surface.

In general, the rheological behavior expected for adhesive mortar, throughout the test, was increased compression load as it increases the displacement of the movable punch due to the approximation of the fraction larger than $0.075 \mathrm{~mm}$ in the mortar. In practice, comparative analysis between the mortar enables the identification of the ease of application by the mason and how it forms over the toothed trowel.

The viscosity of the portion passing through the $0.075 \mathrm{~mm}$ sieve opening (i.e., pulp) was measured in order to determine the influence of the fine fraction (paste) on the rheological behavior of the mortar. This test was performed with a Brookfield Programmable Viscometer DV-II+ Version 5.0.

To determine the amount of air incorporated in the mixtures, density tests were conducted in the fresh state, in addition to bulk density test in the dry state as previously mentioned. Bulk density in the fresh state was determined following the procedure proposed by NBR 13278 [21].

\section{Results and discussion}

Table 2 reflects the proportion of coarse and fine fractions (paste) adhesive mortar, or of material content larger than 75 micron and size of less than 75 micron, respectively. The fine fraction is represented mostly by cement grains and fillers and the coarse fraction by sand grains. Note that Sample D had a higher content of paste than Sample E. 
Table 2 - Reconstitution of the aproximation formulation of adhesive mortars

\begin{tabular}{|lcccccc|} 
& \multicolumn{7}{c|}{ Adhesive mortar } \\
& A & B & C & D & E & F \\
Aggregate (\%) & 74.75 & 75.80 & 74.67 & 70.67 & 80.27 & 74.31 \\
Cement (\%) & 15.86 & 20.70 & 17.77 & 17.90 & 17.86 & 19.52 \\
Limestone filler (\%) & 9.39 & 3.50 & 7.55 & 11.44 & 1.87 & 6.17 \\
Moisture (\%) & 0.13 & 0.10 & 0.16 & 0.15 & 0.16 & 0.15 \\
\hline
\end{tabular}

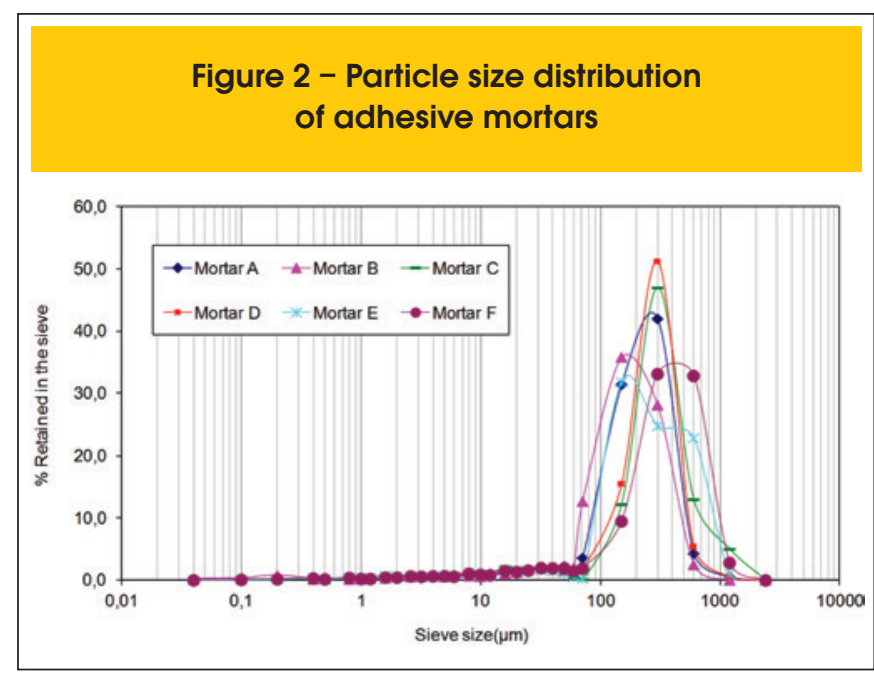

Figure 2 reflects a diverse particle distribution in the mortars and Figure 3 illustrates a specific particle size distribution of fine fraction (particles smaller than $75 \mu \mathrm{m}$ ).

By analyzing the profile of the size distribution curves of the mortar (Figure 2), mortars A, C and D had narrow distributions, which tends to reduce the mean distance of separation between the particles, influencing the rheological behavior of the adhesive mortar. Opened distribution increases the flow benefits, since the smaller grains are more separated from the larger grains, thereby reducing the friction between them. From the data obtained from the sieve analysis, it can be stated that the mortar adhesives have their greatest variations when the particle size distribution is in the range 100 a $1000 \mu \mathrm{m}$, repre-

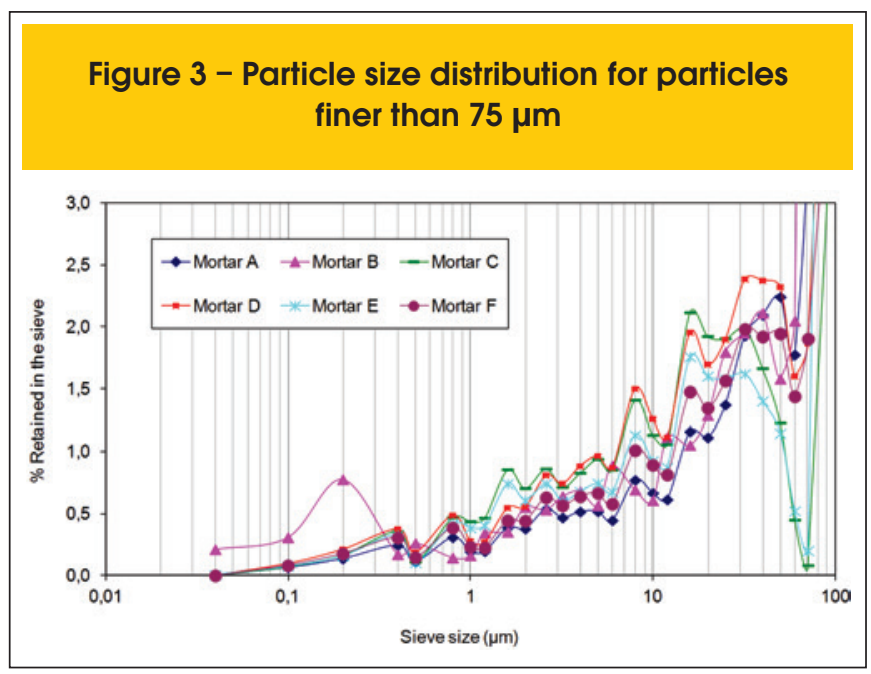

sented by grains larger than $0.075 \mathrm{~mm}$. Table 3 reflects the percentages retained and passed through the sieves with openings of $0.075,0.15,0.3$ and $0.6 \mathrm{~mm}$.

It is possible to verify that there are considerable differences in the percentages retained in each sieve when compared to different mortars in sieves with openings of over $0.075 \mathrm{~mm}$ (coarse fraction). The fine fraction, in turn, showed a similar distribution, without significant differences between them, the only exception being Sample D which differed from the others by at least $5 \%$.

Table 4 reflects the morphological results of particles retained in the sieve openings of $0.15,0.30$ and $0.60 \mathrm{~mm}$ and their coefficients of roundness and the elongation of the grains. Table 5 reflects the bulk density results in the anhydrous and fresh mortar states along

\section{Table 3 - Percent of material retained and Percent of material pass on sieve}

\begin{tabular}{|c|c|c|c|c|c|c|c|c|}
\hline & \multicolumn{2}{|c|}{ Sieve } & \multicolumn{6}{|c|}{ Adhesive mortar } \\
\hline & $\mathrm{mm}$ & mesh & A & B & C & D & E & $\mathbf{F}$ \\
\hline $\begin{array}{c}\% \text { fine fraction } \\
\text { (passing the sieve) }\end{array}$ & 0.075 & 200 & 21.8 & 20.9 & 22.8 & 27.2 & 19.4 & 21.8 \\
\hline \multirow{4}{*}{$\begin{array}{l}\% \text { fine fraction } \\
\text { (retained in the sieve) }\end{array}$} & 0.075 & 200 & 31.2 & 12.7 & 12.2 & 15.6 & 31.8 & 9.5 \\
\hline & 0.15 & 100 & 42.2 & 35.8 & 47.0 & 51.2 & 24.8 & 33.1 \\
\hline & 0.30 & 50 & 4.3 & 28.1 & 13.0 & 5.4 & 22.9 & 32.8 \\
\hline & 0.60 & 30 & 0.5 & 2.5 & 5.0 & 0.6 & 1.1 & 2.8 \\
\hline
\end{tabular}


Table 4 - Morphological characterization of the coarse sand fraction in the adhesive mortars

\begin{tabular}{cccccccccc|} 
& \multicolumn{2}{c}{ Sieve } & \multicolumn{7}{c|}{ Adhesive mortar } \\
& $\mathrm{mm}$ & mesh & A & B & C & D & E & F \\
Roundness & $0.15 \mathrm{~mm}$ & 100 & 0.518 & 0.509 & 0.508 & 0.492 & 0.492 & 0.506 \\
& $0.3 \mathrm{~mm}$ & 50 & 0.521 & 0.525 & 0.502 & 0.522 & 0.490 & 0.792 \\
& $0.6 \mathrm{~mm}$ & 30 & 0.500 & 0.504 & 0.474 & 0.516 & 0.521 & 0.496 \\
Sphericity & $0.15 \mathrm{~mm}$ & 100 & 0.728 & 0.706 & 0.730 & 0.678 & 0.717 & 0.735 \\
& $0.3 \mathrm{~mm}$ & 50 & 0.738 & 0.734 & 0.700 & 0.729 & 0.685 & 0.755 \\
& $0.6 \mathrm{~mm}$ & 30 & 0.729 & 0.699 & 0.662 & 0.720 & 0.733 & 0.696 \\
\hline
\end{tabular}

Table 5 - Specific gravity and the air entrained content in the adhesive mortar

\begin{tabular}{|cccccccc|} 
& & \multicolumn{7}{c|}{ Adhesive mortar } \\
& & A & B & C & D & E & F \\
Specific gravity & Dry & 2.70 & 2.70 & 2.60 & 2.65 & 2.60 & 2.60 \\
Air entrained content & Fresh & 1.45 & 1.60 & 1.55 & 1.75 & 1.70 & 1.50 \\
& Fresh & 28.2 & 21.9 & 22.9 & 15.7 & 15.5 & 26.6 \\
\hline
\end{tabular}

with the incorporated air content in fresh state mortar when using the manufacturer designated water content.

In the results it was observed that the mortars had similar rounded particles (in the range of 0.474 to $0.521 \mathrm{~mm}$ ) except for Sample F (fraction $0.3 \mathrm{~mm}$ sieve) which had superior rounding (0.792) compared to the other samples. It is also possible to verify that mortar clusters have similar elongation coefficients in the range of 0.662 to 0.755 .

In regard to the bulk density of an anhydrous mixture, the mortar exhibited variations in a very narrow range between 2.63 and 2.67 $\mathrm{g} / \mathrm{cm}^{3}$. This can be attributed to the inherent variability of the test method (on the order of $1.5 \%$ ). However, for the mortar analyzed, the differences resided in the fresh state bulk density which was in the range between 1.46 and $1.71 \mathrm{~g} / \mathrm{cm}^{3}$.

These differences may arise in chemical and physical changes caused by the reactivity of cement, additives and the mixing procedure, resulting in a distribution of constituents other than that present in the anhydrous state. The cement determines hydrated components in the hardened mixture. Additives, and the mixing procedure itself, will incorporate air into the fresh mixture. Throughout the tests, there was a strong correlation between fresh state bulk density and incorporated air content $\left(R^{2}=0.9693\right)$. $A$ variation in the level and type of additives can have a significant impact on the behavior of fresh mortar. It was not the purpose of this research to determine the quantitative data associated with these variations.

Figure 4 reflects the viscosity of a mixture as a function of shear rate. The data obtained in the tests indicated that all mixtures had pseudoplastic behavior, i.e., there was a decrease in viscosity with a corresponding increase in shear rate. Although, with different mortar viscosities between 0 a $50 \mathrm{~S}^{-1}$, the data indicates a tendency of similar viscosities at higher shear rates similar to those in the Squeeze Flow tests. Thus, it was not considered pertinent in this research to indicate viscosity as a variable in the assessment of the rheological behavior of mortar. The profile curves obtained in the Squeeze Flow test for adhesive mortar are reflected in Figure 5.

The curves in Figure 5 show that adhesive mortar exhibits different rheological characteristics as indicated by each mortar having distinct compression loading absorption capacity when imposed by the movable punch equipment.

Sample $C$ had a higher compressive load as compared to the other samples which resulted in greater spreading difficulty and deformation of the strings. Sample F had greater fluidity as compared to the others which would result in easier spreading and formation of the strings but would probably result in excessive slippage of the ceramic tile. As it was not possible to obtain a parameter of effort

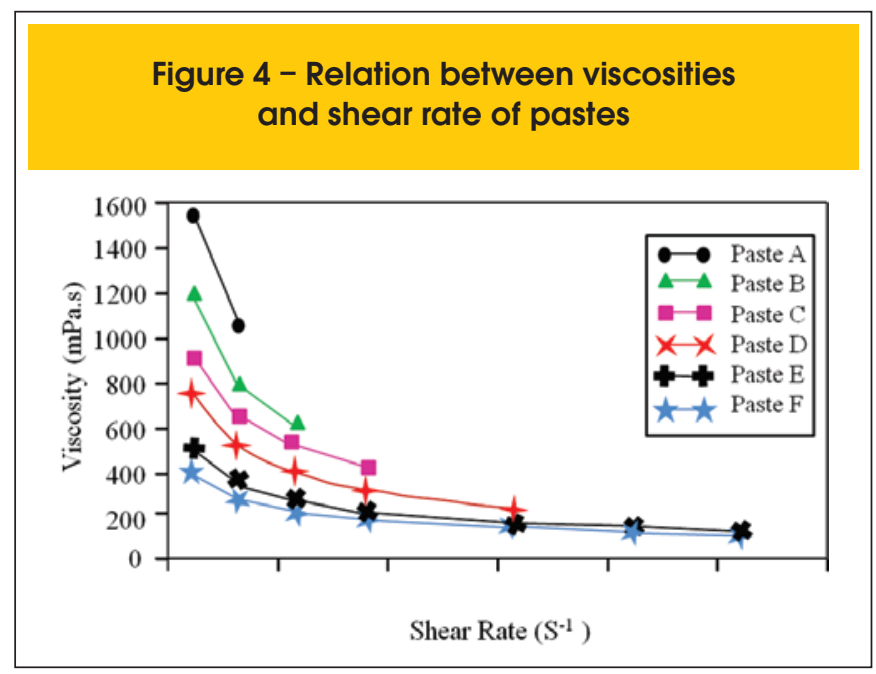




\section{Figure 5 - Curve shape of load versus displacement of adhesive mortars, obtained with the Squeeze Flow test}

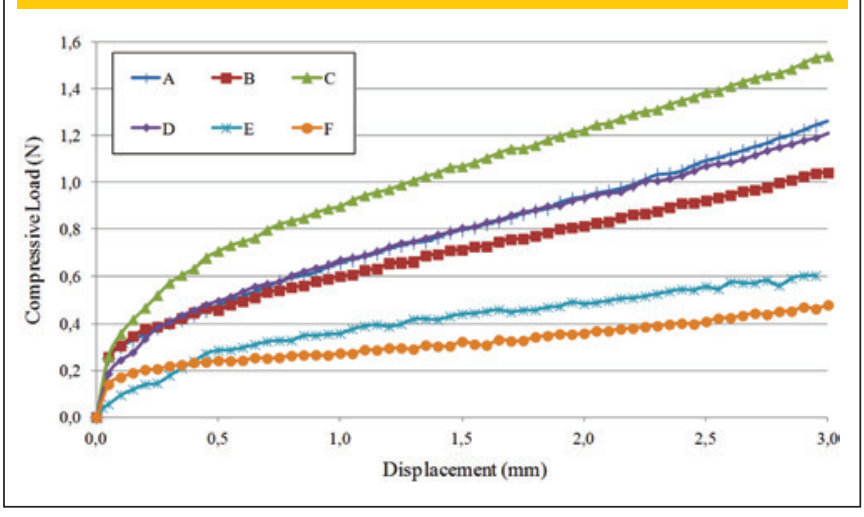

applied by the mason for determining spreading and bead formation, it cannot be stated that Sample $\mathrm{C}$ does not provide satisfactory spreading and bead formation. Probably the six studied mortars are acceptable for use in coatings. The analysis that was performed was comparative and the results obtained were restricted to the water/ dry material relationship indicated by the manufacturer.

Table 6 highlights the analyzed parameters of this research and demonstrates the significant influence that particle size has on the rheological behavior of the adhesive mortars studied compared to the results obtained by the Squeeze Flow test. The numerous influential parameters are indicated in this table as high (a), intermediate (a) or low (a). Morphology is classified as either irregular or regular. When the mortar exceeds a parameter, it is indicated with a + sign.

Comparing the Squeeze Flow test results to the data obtained from mortar property analysis, it was concluded that the primary influential parameter on the performance of the mortar used in this study was particle size distribution of grains larger than $0.075 \mathrm{~mm}$. Calculating correlations between various properties analyzed, the percentage of aggregate retained between sieves with aperture 0.3 to $0.15 \mathrm{~mm}$ was shown to be more significant. This behavior might best be explained by the phenomenon of imbrication of grains, i.e., rapprochement between the aggregates and the consequent friction between them during flow, which directly influence the yield strength of mortar.
Samples A, C and D had a narrow distribution, which reduces the average distance of separation between the particles and hinders the flow. This effect was observed in the tests where mortar had the highest compressive loads. It was determined in Sample $C$ that narrow particle size distribution was decisive in achieving superior maximum load compression. It was determined in Sample A that narrow particle size distribution overcomes the effects of high incorporated air levels, resulting in a compressive load inferior to that of Sample C. Sample D exhibited low levels of incorporated air and narrow particle size distribution resulting in a high compressive load. Sample D also had a higher content of fines than the other samples. It is possible that the water content of the mixture was not sufficient to ensure adequate mixture flow.

Despite the similarities in particle size distribution between the samples, the maximum compression loads were different. This is probably due to the combined effect of high levels of incorporated air in the mortar. The lowest compression loads were represented by Samples $E$ and F. Both of these samples had open size distribution but differed in the content of incorporated air.

In Sample E, grain size was decisive in compressive loading in that it had more significant effect than a low level of incorporated air. The low load compression level in Sample $F$ resulted from high levels of incorporated air, open particle size distribution and in the morphological characteristics of particles highlighted by lower level of roughness.

The observed results of the samples confirm the conclusions obtained by Cardoso [14] in his doctoral thesis where he indicated that open particle size resulted in smaller voids in the mortar and lower loads in the Squeeze Flow test while narrow particle size distribution resulted in larger voids and higher loads in the Squeeze Flow test.

The morphology of the aggregates allowed the verification of its influence on rheological behavior. Specifically in Sample F, rounded grains acted together with incorporated air, particle size distribution and reduced compression load.

After analyzing the results, it was determined that it is likely that there is a synergistic relationship between particle size distribution, incorporated air content and morphology on the load compression obtained in the Squeeze Flow test. However, it is noteworthy to consider that, even with mortar additives, a portion of these observed behaviors may have been due to these synergistic relationships, thus creating the necessity for further investigation on the subject.

Table 6 - Summary of the adhesive mortars analysis

\begin{tabular}{cccccc}
$\begin{array}{c}\text { Adhesive } \\
\text { mortar }\end{array}$ & $\begin{array}{c}\text { Compressive } \\
\text { load (N) }\end{array}$ & $\begin{array}{c}\text { Paste viscosity } \\
\text { (mPa.s) }\end{array}$ & $\begin{array}{c}\text { Particle size } \\
\text { distribution }\end{array}$ & $\begin{array}{c}\text { Air entrained } \\
\text { content (\%) }\end{array}$ & Roundness \\
A & High (1.26) & Intermediate (64) & Narrow & + High (28.2) & Irregular (0.518) \\
B & Intermediate (1.20) & Intermediate (66) & Open & Intermediate (21.9) & Irregular (0.515) \\
C & + High (1.54) & Intermed/Low (45) & + Narrow & High (22.9) & Irregular (0.504) \\
D & High (1.21) & Low (21) & Narrow & Low (15.7) & Irregular (0.495) \\
E & Low (0.62) & Intermediate (66) & + Open & + Low (15.5) & Irregular (0.492) \\
F & + Low (0.48) & High (87) & Open & High (26.6) & Regular (0.616) \\
\hline
\end{tabular}




\section{Conclusions}

The experimental program proposed in this research yielded the following conclusions:

- The profile and load level data curves obtained from the tests are sufficient for understanding the rheological behavior of mortar;

- The adhesive mortar utilized in this study reflected different rheological characteristics, each mixture indicating distinct compression loading absorption capacity imposed by the mobile punch equipment;

- It was observed that there is a synergistic relationship between particle size distribution, the amount of incorporated air and grain morphology on the compressive load of the mortar;

- Size distribution and the morphology of the grains, within the size range of $0.3-0.15 \mathrm{~mm}$, were indicated as the most influential parameters for the studied adhesive mortars.

\section{References}

[01] JENNI, A; ZURBRIGGEN, R; HOLZER, L; HERWEGH, $M$. Changes in microstructures and physical properties of polymer-modified mortars during wet storage. Cement and Concrete Research. Volume 36. 2005a.

[02] JENNI, A; ZURBRIGGEN, R; HOLZER, L; HERWEGH, $M$. Influence of polymerer on microstructure and adhesive strength of cementitiuos tile adhesive mortars. Cement and Concrete Research. Volume 36 2005b.

[03] SANTOS, N. Avaliação de micro e nanoporosidade de argamassas colantes. Dissertação de Mestrado, Programa de Pós Graduação em Engenharia Civil da Universidade Federal de Santa Catarina - UFSC, Florianópolis (SC), 2006.

[04] SENNA, D. O. Avaliação do comportamento das argamassas modificada por polímeros à base de éter de celulose em ambientes agressivos. Dissertação de Mestrado. Programa de Pós Graduação em Engenharia Civil e Ambiental. Departamento de Tecnologia. Universidade Estadual de Feira de Santana. Feira de Santana - Bahia. 2008

[05] MANSUR, A. A. P. Mecanismo físico-químico de aderência na interface argamassa modificada com polímeros/cerâmica de revestimento. Tese (Doutorado), Universidade Federal de Minas Gerais.

Belo Horizonte. 2007.

[06] MENDES, T. M. Influência do coeficiente de atrito entre os agregados e da viscosidade da matriz no comportamento reológico de suspensões concentradas heterogêneas. Dissertação de Mestrado. Escola Politécnica da Universidade de São Paulo - USP. São Paulo (SP). 2008.

[07] PEREIRA, E. Estudo da influência das propriedades de argamassas colantes na resistência de aderência de revestimentos cerâmicos aplicados no assentamento de piso sobre piso. Dissertação (Mestrado). Programa de Pós-Graduação em Engenharia de Construção Civil. Universidade Federal do Paraná. Curitiba, 2012.
[08] COSTA, M. R. M. M. Análise comparativa de argamassas colantes de mercado através de parâmetros reológicos. Tese de Doutorado, Escola Politécnica da Universidade de São Paulo - USP, São Paulo (SP), 2006.

[09] ANTUNES, G. R. Estudo de Manifestações Patológicas em Revestimentos de Fachada em Brasília Sistematização da Incidência de Casos. Dissertação de Mestrado. Universidade de Brasília. Distrito Federal. 2010.

[10] MANSUR, A. A. P; NASCIMENTO, O. L; MANSUR, H. S. Physico-chemical characterization of EVA-modified mortar and porcelain tiles interfaces. Cement and Concrete Research. Volume 39. pp 1199-1208. 2009.

[11] OLIVEIRA, I.R. ; STUDART, A.R. ; PILLEGI, R.G. ; PANDOLFELLI, V.C. Dispersão e empacotamento de partículas : princípios e aplicações em processamento cerâmico. 18 ed. Fazendo arte editorial, 195 p, 2000.

[12] PILEGGI, R. G. Ferramentas para o estudo e desenvolvimento de concretos refratários. 2001. 187p. Tese de doutorado. Universidade de São Carlos, 2001.

[13] BAUER, E. Revestimentos de argamassa características e peculiaridades. 1. ed. BRASÍLIA: LEM-UnB - SINDUSCON/DF. 2005.

[14] CARDOSO, F. A. Método de formulação de argamassas de revestimento baseado em distribuição granulométrica e comportamento reológico. Tese de Doutorado. Escola Politécnica da Universidade de São Paulo USP. São Paulo (SP). 2009.

[15] ASSOCIAÇÃO BRASILEIRA DE NORMAS TÉCNICAS. Argamassa de assentamento e revestimento de paredes e tetos - Caracterização reológica pelo método squeeze-flow - NBR15839. Rio de Janeiro, 2010

[16] KUDO, E. K; CARDOSO, F. A; PILEGGI, R. G. Squeeze Flow aplicado a argamassas colantes: influência de parâmetros experimentais de configuração e taxa de deslocamento. In: IV Simpósio brasileiro de tecnologia de argamassas. Anais do IV SBTA. Belo Horizonte. 2011.

[17] ASSOCIAÇÃO BRASILEIRA DE NORMAS TÉCNICAS. Argamassa colante industrializada para assentamento de placas cerâmicas - Especificações - NBR 14081. Rio de Janeiro, 2004.

[18] ASSOCIAÇÃO BRASILEIRA DE NORMAS TÉCNICAS. Argamassa colante industrializada para assentamento de placas cerâmicas - Determinação do deslizamento - NBR 14085. Rio de Janeiro, 2004.

[19] QUARCIONI, V. A. Reconstituição de traço de argamassas: atualização do Método IPT. Dissertação (Mestrado) - Escola Politécnica, Universidade de São Paulo. São Paulo, 1998.

[20] ESSS - Engineering Simulation and Scientific Software: Fatores de forma - Descrição e usabilidade dos fatores de forma na plataforma IMAGO. Florianópolis, 2005. 19 p. Relatório.

[21] ASSOCIAÇÃO BRASILEIRA DE NORMAS TÉCNICAS. Argamassa para assentamento de paredes $\mathrm{e}$ revestimento de paredes e tetos - Determinação da densidade da massa e do teor de ar incorporado NBR 13278. Rio de Janeiro, 2004. 